\title{
Visual ecology of the fiddler crab, Uca tangeri: effects of sex, viewer and background on conspicuousness
}

\author{
MOLLY E. CUMMINGS*, JOANA M. JORDÃO†, THOMAS W. CRONIN $\&$ RUI F. OLIVEIRA† \\ *Section of Integrative Biology, University of Texas at Austin \\ $\dagger$ Unidade de Investigacao em Eco-Etologia, Instituto Superior de Psicologia Aplicada, Lisboa, Portugal \\ $\ddagger$ Department of Biology, University of Maryland at Baltimore County, U.S.A. \\ (Received 19 June 2006; initial acceptance 24 September 2006; \\ final acceptance 9 April 2007; MS. number: A10479R)
}

\begin{abstract}
We investigated the visual ecology of the coloration of the eastern Atlantic fiddler crab, Uca tangeri, with particular attention to predator (e.g. avian) and conspecific vision. Spectral reflectance measurements were made on different body parts used in possible intraspecific communication as well as background habitats including crab-made materials (e.g. mudballs). Avian-based and crab-based visual models were used to obtain different estimates of crab conspicuousness to potential predators and conspecifics. We found that male body parts (except for dorsal carapace) were significantly more conspicuous to conspecific viewers than female equivalent body parts, and showed greater within-body contrast estimates. Moreover, male major claw areas differed in reflectance properties, producing variation in conspicuousness that fit signalling predictions: areas visible during claw-waving events were most conspicuous against the background sky, whereas areas visible in nonwaving positions were more conspicuous against substrate backgrounds. For avian vision, sexually dimorphic coloration results in males being generally more conspicuous than females (in terms of brightness contrast) against all backgrounds, however, there was no sexual dimorphic conspicuousness of carapace coloration. Furthermore, one of the most conspicuous features of both male and female crabs is an area that is likely to be more visible to crabs (mouthparts) than to avian predators from above. While conspicuousness varies with background, the most conspicuous background for male signalling parts (major claw) is dark mudballs, suggesting that males may increase the conspicuousness of their signals by modifying their signalling environment.
\end{abstract}

(c) 2007 The Association for the Study of Animal Behaviour. Published by Elsevier Ltd. All rights reserved.

Keywords: avian vision; coloration; conspicuousness; fiddler crab; visual ecology; Uca tangeri

Fiddler crabs represent a rich model system for examinations of sensory processes and behaviour. Their stereotypical displays, specific visual tasks, relatively simple environment and dynamic social interactions have made them an ideal system for identifying the sensory system contribution to many behaviours such as tracking conspecifics (Land \& Layne 1995), finding burrows (Hemmi \& Zeil 2003a, b), neighbour and species recognition (Detto et al. 2006) and attracting mates (Christy 1995). Fiddler crabs have also become an important model system in sexual selection, as many studies have examined how male displays and burrow ornamentation influence

Correspondence: M. E. Cummings, Section of Integrative Biology CO930, University of Texas, Austin, TX 78712, U.S.A. (email: mcummings@mail.utexas.edu). female mate choice behaviour (Christy 1983, 1988; Backwell et al. 1995; Oliveira \& Custodio 1998; Oliveira et al. 1998; Pope 2000; Christy et al. 2003a, b). This comprehensive body of research has provided insights into sexual selection (e.g. sensory trap hypothesis; Christy 1995) and has provided predictions for the direction of signal evolution (e.g. Christy \& Backwell 2006). To date, much of the focus of signalling behaviour has been on claw-waving displays or the structures that males build to attract females and repel rivals. Yet, more recent studies (see Zeil \& Hofmann 2001; Detto et al. 2004; Hemmi et al. 2006) have examined the coloration features of the signalling display (e.g. body, claw, background coloration). Here, we explore whether the coloration of specific body parts in fiddler crab is adaptive in terms of avoiding predation and enhancing communication, given what we know 
about fiddler crab signalling behaviour (waving) and their signalling environment.

Visual signalling in fiddler crabs is an important aspect of intraspecific communication and sexual selection in these species (e.g. Latruffe et al. 1999). As in many other animal systems, signalling conspicuousness can vary with differences in (1) signal properties, (2) behaviour, (3) environmental light properties, (4) background and (5) the viewer's perceptual system. And in the fiddler crab system, all of the above are likely to play a role. Males signal with body parts (claws) that differ phenotypically from the rest of their body. They use behaviour to advertise to females (waving claws), and to modify their visual background (roll mudballs in front and behind their burrows). And, as with many organisms, the signals that make them conspicuous to conspecifics can also be conspicuous to unintended receivers (e.g. predators; Endler 1987). In a previous study, using human observers as a model of visual predators Jordão \& Oliveira (2001) showed that the size and colour of the male fiddler crab's major claw can be very conspicuous to humans against the mudflat background. Nevertheless, to understand how selection pressures shape the colours and signalling behaviours of these animals it is necessary to consider all the variables involved in their visual ecology: habitats with different visual characteristics, different displaying tasks between males and females and different potential risks according to habitat and/or sex.

As in most fiddler crab species, fiddler crab males wave their major claw to announce their presence to potentially receptive females (Crane 1975; Pope 2005). In the case of fiddler crab, a lateral waver (Crane 1975), the major claw produces an oblique shaped movement, with the cheliped being fully extended laterally, raised high above the body, and finally folded and lowered in a frontal plane in relation to the crab's body (von Hagen 1962). Waving can also be directed at other males in a territorial context, and the simple presence of the major claw seems to be the main cue for sex recognition by both males and females (von Hagen 1962). Males also produce mudballs that they arrange in a visual display around their burrow opening to reduce agonistic interactions between neighbouring males and to attract females (Oliveira et al. 1998). Two types of mudballs can be produced in this population: light-coloured (sand-based) or dark-coloured (anoxic mud), with no colour gradient in between. Here, we will explore the differences in conspicuousness for important body parts in front of these and other visual backgrounds. We will examine conspicuousness in a sample of individuals from a single fiddler crab population at both the intraspecific (sexual dimorphism) and interspecific (potential predator) levels.

In this system, there are only three classes of 'players' with well-defined visual roles: male and female $U$. tangeri and potential bird predators; and two possible habitat types: mudflat and salt marsh vegetations. Although this population of $U$. tangeri in southern Portugal does not have as many natural predators as $U$. tangeri in the west coast of Mauritania (Ens et al. 1993), there are some reports of avian predation (von Hagen 1962; Faria 1995; Machado 1996). Also, both male and female crabs react to the presence of approaching birds (von Hagen 1962; J. M. Jordão, personal observation) or an approaching bird predator model (R. F. Oliveira, unpublished data). There are several reports suggesting that predation is sexually differential in several species of fiddler crabs (e.g. Wolf et al. 1975; Ribeiro et al. 2003). Females are usually more predated upon than males, since males can use their major claw for defence. Also, given a choice in the laboratory, ibises avoid male Uca pugilator because of the added handling difficulty (Bildstein et al. 1989). However, reverse sexually biased predation has also been observed. Koga et al. (2001) report a strong male-biased predation rate by great-tailed grackles, Quiscalus mexicanus, on Uca beebei (three times less than that on $U$. tangeri). It is conceivable the male claw of $U$. beebei does not pose a threat to avian predators, whereas the much larger major claw of male $U$. tangeri poses a serious threat (or at least handling problem) to any likely avian predator and, for that reason, females are possibly preferential prey in this species.

The most relevant body part in the male waving display is the major claw (both the exterior and interior regions). In the beginning of the display, when the claw is in the resting position, conspecifics have a view of the outside of the claw against the mouthpart of the signaller. When it is unfolded and in an upright position during a waving display, the signaller exposes the inside of the claw against the sky (in an open mudflat), against the mudflat surface itself or mudballs (in a steep mudflat), or against vegetation (in a salt marsh). The dorsal carapace and legs, on the other end, are the body parts more easily seen from above (Fig. 1). The body coloration of $U$. tangeri is relatively dull, at least to the human eye, compared to other fiddler crab species. The colour of carapace, legs and other appendages ranges from purple to brownish (Fig. 1). Apart from the white coloration of the males' enlarged claw, there are no apparent sex differences in body coloration and there is also no obvious change in body coloration in periods of more intense social activity or upon capture.

Since males advertise burrow location to females using enlarged claws and claw-waving behaviour in front of natural (sky and mudflat vegetation) and modified background materials (mudballs), we can make specific predictions about the visual saliency of specific body coloration and visual ecology of $U$. tangeri. Specifically, we predict that from a crab's point of view: (1) males should be generally more conspicuous than females (against all possible backgrounds); (2) major claws should be the most conspicuous male body part against all backgrounds; (3) male claw parts should maximize conspicuousness in all socially relevant positions (e.g. the outside of the male's major claw should be conspicuous against the male's mouthparts for sex recognition signalling, and the inner claw should show greater contrast to relevant backgrounds during claw-waving events); (4) mudballs (structures constructed by the males) should increase a male's conspicuousness relative to the other possible backgrounds (sky or mudflat vegetation); and (5) lastly, from an avian predator point of view, body parts easily seen from above, such as the dorsal carapace and legs, should be cryptic against the mudflat and salt marsh vegetation backgrounds. 

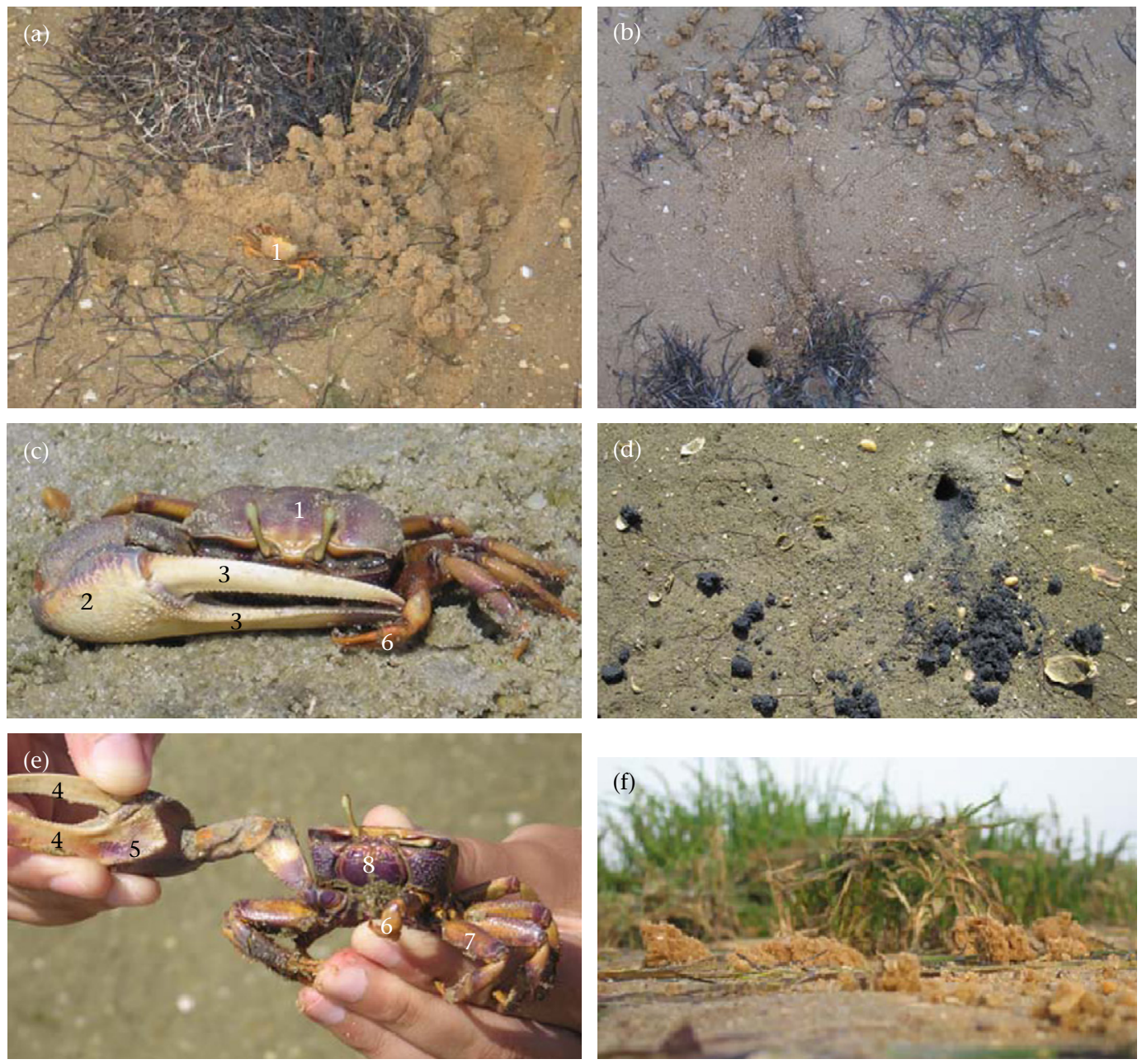

Figure 1. Photos of male $(\mathrm{M})$ and female $(\mathrm{F})$ U. tangeri with relevant body parts, and different mudball types. (a) Typical $\mathrm{F}$ mudball (light) arrangement; (b) typical M mudball (light) arrangement; (c) front view of M (closed claw); (d) dark mudballs; (e) front view of $\mathrm{M}$ (open claw); and (f) mudballs and mudflat vegetation from the crab's point of view. (1) Dorsal carapace (M and F); (2) manus (M); (3) exterior dactyl and pollex (M); (4) inner dactyl and pollex (M); (5) purple pigmentation inside manus (M); (6) minor claw (M and F); (7) ambulatory leg (M and F); and (8) mouthpart (M and F).

\section{METHODS}

To characterize the conspicuousness of crab body parts we (1) measured the inherent spectral reflectances of crabs and background using a regulated, full-spectrum light source and standardized angles of illuminant and receiving fibre optics; (2) measured the light conditions during behavioural displays; and (3) used vision models to assess the colour and brightness contrast of crabs viewed against the different background materials by different viewers (crab or avian). As in most conspicuous characterization studies, we fall short of including all aspects of the visual scene that contribute to the perceived conspicuousness (e.g. angle of observation, see Zeil \& Hemmi 2006), yet this represents a first approximation of how differences in coloration may increase or decrease the detectability of a body part dependent on the viewer. We chose to measure spectral reflectance under controlled laboratory conditions to control for changes in the light field and angle of illumination that occurs during outdoor measurements. Once the inherent spectral reflectance properties are measured, the estimated radiance $(L$, the light reflected from an object under specific light conditions) can be evaluated for some typical illuminant conditions (early and late afternoon sun conditions). These estimates of crab and background radiances were then evaluated by models estimating how conspecifics and potential predators 'see' these different body parts.

\section{Spectral Reflectance Measurements}

Spectral reflectance measurements were collected from 20 female (average carapace width \pm SD: $2.63 \pm 0.17 \mathrm{~cm}$ ) and 20 male (average carapace width \pm SD: $3.15 \pm$ $0.14 \mathrm{~cm}$ ) fiddler crabs. Crabs were collected between 22 and 24 July 1999 and reflectance measurements were made within $6 \mathrm{~h}$ of collection.

Fiddler crab reflectances were measured using an Ocean Optics PS1000 spectrometer with illumination provided by an Oriel $150 \mathrm{~W}$ Xenon lamp (model 6255) as described in Cummings (2004). The illumination fibre was fixed at 
a $30^{\circ}$ angle incident to the body of the crab, and the receiving apparatus (focusing assembly feeding into the spectrometer) was positioned normal $\left(90^{\circ}\right)$ to the surface of the crab. This set-up assumes a low angle of illumination (to mimic our irradiance measurements collected late in the day) and assumes that the viewer is parallel to the substrate (e.g. a conspecific crab), thereby limiting a more accurate assessment of any potential predator's view from above. Reflected illumination was collected by a focusing assembly consisting of a $25.4-\mathrm{mm}$ fused silica biconvex lens (Edmund Scientific UV DCX L08-016) fitted in a telescope adapter (Orion model 5264) and attached with a T-ring to a 35-mm camera body. A 400- $\mu$ m UV-vis (Ocean Optics, Inc.) fibre optic was fixed with an SMA connection to the back of the camera body at the film plane and received the focused reflectance when the shutter release was pressed and the mirror was removed from the path of light. The focusing assembly used a biconvex fused silica lens to focus the surface reflectance from a $1-2 \mathrm{~mm}^{2}$ diameter area of the crab body onto the $400-\mu \mathrm{m}$ fibre optic that fed directly into an Ocean Optics PS1000 (UV-vis grating) spectrophotometer. All reflectance values are relative to a 99\% (300$700 \mathrm{~nm}$ ) reflectance standard (Spectralon ${ }^{\mathrm{TM}}$, Labsphere, North Sutton, NH, U.S.A.). Three reflectance spectra were collected from each spot, and six regions were measured from each male and female from the following areas: dorsal and ventral carapace, right and left claws (including exterior dactyl and pollex, manus and inner dactyl and pollex, and blue/purple pigmented dots on the interior manus, in the case of males; Fig. 1), ambulatory leg (merus region), and mouthparts. All crabs in this study were treated by ethical guidelines following the Portuguese law for the use of animals in scientific research and the ABS/ASAB Guidelines for the Treatment of Animals in Behavioural Research and Teaching, and were released back into their specific habitats within $30 \mathrm{~h}$ of collection.

For consistency in modelling, reflectance spectra of background materials were measured in the same way as crab reflectances. Background reflectance measurements were made on specific features in the crabs' direct background (e.g. mudballs and mudflat vegetation). Mudballs and clumps of mudflat vegetation (Zostera marina and Cymodocea nodosa) were collected from $14 \mathrm{U}$. tangeri male burrows. Seven of the 14 burrows had very dark mudballs positioned around the crab's burrow entryway, while the other half of the burrows had mudballs of very light-coloured substrate (see Fig. 2c), similar to the substrate surface material. Substrate and mudballs were collected at sunset and brought back to the laboratory for reflectance measurements that same evening using the reflectance set-up described above, and the same incident light angle $\left(30^{\circ}\right.$ from horizontal). Mudflat vegetation clumps were kept in a moist bucket until measurements were made.

\section{Field Radiance Measurements}

To evaluate whether colour properties of burrow material (mudballs) changed in transit from the field to the laboratory, we measured mudball and surrounding sand/mud radiances in the field on three different days (20, 22 and 24 July). Field radiance measurements were collected using a $400-\mu \mathrm{m}$ fibre optic with a $23^{\circ}$ angle of acceptance (0.401 radians) hand-held directly above the mudball at approximately $2 \mathrm{~cm}$ distance. Radiance measurements of the surrounding sand material were also collected in a paired fashion to compare spectral qualities of sand and mudballs surrounding the burrow. Paired measurements of sand and mudball radiances (8/burrow) were collected at burrows with light and dark mudballs on each day (20 July at 1615 hours: four 'light' burrows; 22 July at 1715 hours: two 'light' burrows and four 'dark' burrows; 24 July at 1815 hours: six 'light' burrows and four 'dark' burrows). These direct radiance measurements were then compared with the estimated radiance values for 24 July (where radiance is roughly approximated as: $L(\lambda)=I_{i}(\lambda) R(\lambda)$, where $I_{i}(\lambda)$ is the illuminant irradiance at 1815 hours on 24 July and $R(\lambda)$ is the mean mudball or sand reflectance).

\section{Habitat Irradiance Measurements}

Early and late afternoon spectral irradiance measurements were measured on mudflat and salt marsh environments while $U$. tangeri males were displaying, at Ria Formosa Natural Park, Southern Portugal, from 20 to 24 July 1999, between 1430 and 1815 hours. Irradiance measurements were collected with a spectroradiometer (Ocean Optics PS1000, a 400- $\mu \mathrm{m}$ fibre optic connected to a cosine collector; see Cummings \& Partridge 2001 for details). Measurements were taken oriented towards the sun (the illuminating light field) and orthogonal to the sun (the visually adapting light field). Note that irradiance measurements collected in parallel with the substrate include the very bright white light present along $5^{\circ}$ off the horizon as well as blue ( $>5^{\circ}$ off horizon). Hence, these irradiances may overestimate the blue sky component to a crab viewer's visual field (see Zeil \& Hemmi 2006). Conspicuousness estimates (see below) were evaluated using two sets of irradiance measurements: early (1430 hours) and late (1815 hours) afternoon.

\section{Vision Models}

To evaluate the conspicuousness of the different colour patterns, we used an avian tetrachromatic visual model (described in Darst et al. 2006) and a simple crab visual model. The avian visual model is similar to Siddiqi et al.'s (2004) model including both chromatic (spectral, $\Delta \mathrm{S}$ ) and achromatic (brightness, $\Delta \mathrm{B}$ ) channel discriminations, and uses passerine spectral sensitivities to estimate photon capture (Hart et al. 1998). Spectral sensitivities of birds have been classified into two main groups: those containing ultraviolet sensitive (UVS) cone photoreceptors while others contain violet sensitive (VS) cone photoreceptors. Gulls, likely avian predators on fiddler crabs, express UVS visual pigments similar to passerines (Ödeen \& Håstad 2003), and hence a passerine or UVS avian visual system is probably appropriate for estimating potential predator visual capabilities. For the $U$. tangeri-specific 

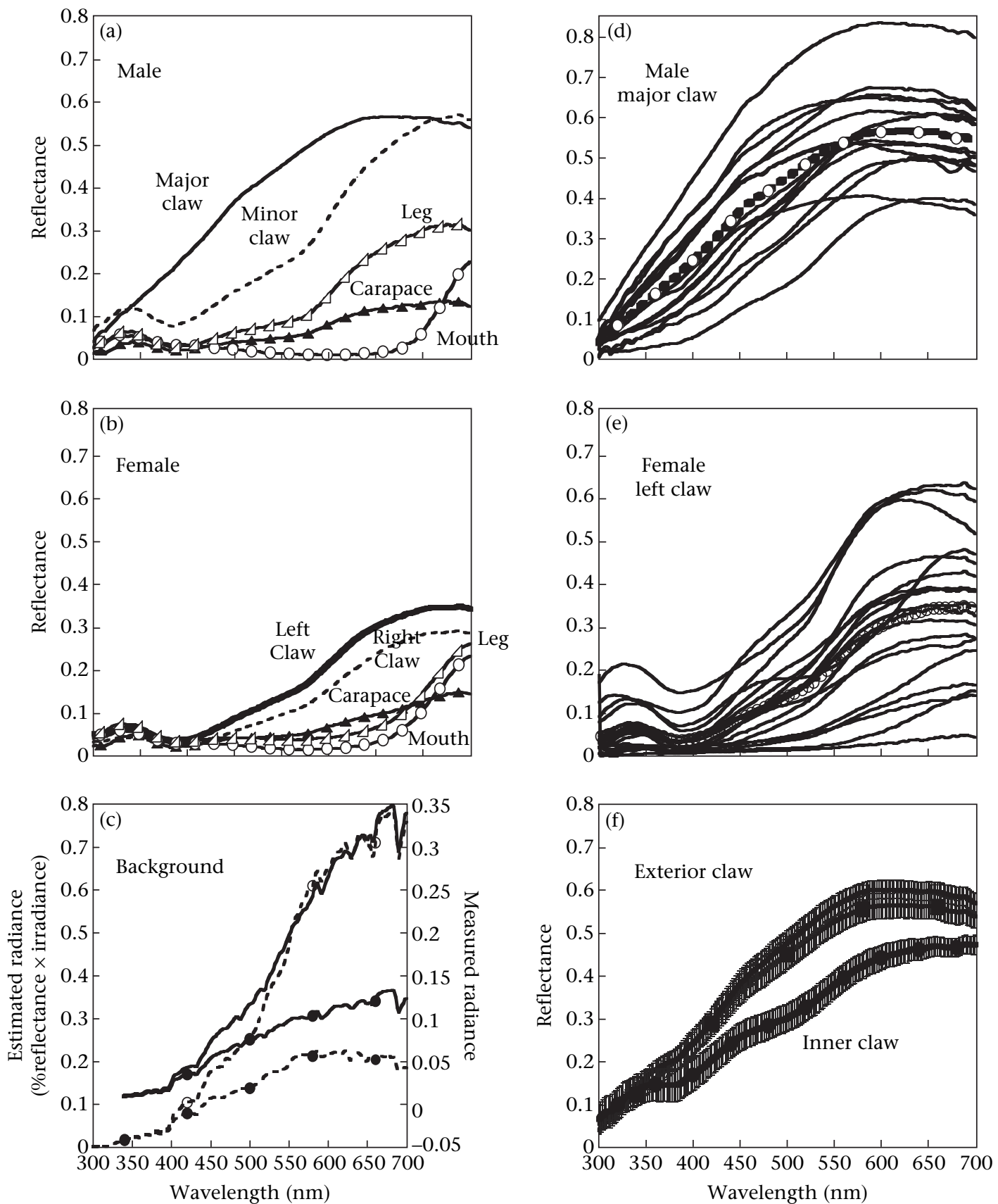

Figure 2. Uca tangeri body part and background spectral reflectances measurements. (a) Average male $U$. tangeri reflectances for manus or major claw ( $-: N=15$ males [45] reflectances), minor claw $(\cdots: N=18$ [54]), mouthparts $(O: N=18$ [54]), dorsal carapace ( $\Delta: N=17$ [51]), and ambulatory leg $(\triangle: N=17$ [51]). (b) Average female $U$. tangeri reflectances for left claw ( $-N=20$ females [60] reflectances), right claw $(\cdots: N=20[60])$, mouthpart $(O: N=20$ [60]), dorsum carapace $(\Delta: N=20[60])$, ambulatory leg $(\triangle: N=20[60])$. (c) Measured radiance in $u \mathrm{E} / \mathrm{m}^{2} / \mathrm{s} / \mathrm{sr}$ (solid lines) and estimated radiance (dashed lines) using the average $U$. tangeri background reflectances collected near 14 different burrows, dark mudballs ( $: N=7$ [21]), light mudballs $(O: N=7$ [21]), and mudflat vegetation (data not shown). Radiances were measured on 24 July 1999 at 1815 hours with sun low in sky and a hand-held fibre optic with $23^{\circ}$ field of view acceptance angle. Estimated radiance values represent the product of the reflectance measurements (collected in the laboratory under constant conditions) and the irradiance measurements collected on 24 July 1999 at 1815 hours. (d) Individual mean spectral reflectances $(N=3$ reflectances per male) of major claw for 15 males ( $O$ : average spectrum). (e) Individual mean spectral reflectances $(N=3$ reflectances per female) of left claw for 20 females $(\bigcirc$ : average spectrum). (f) Mean \pm SE reflectances from 15 males for different regions of the male major claw: exterior ( $\boldsymbol{\square}$ : dactyl and pollex; $\square$ : manus) and interior dactyl and pollex (@) regions.

model, we incorporated the visual pigment spectral sensitivity and screening pigment data for this species (Jordão et al. 2007) into a simple model assuming a single-receptor brightness contrast. We also estimated a hypothetical spectral discrimination channel of a fiddler crab based on a potential dichromatic spectral sensitivities measured in Uca thayeri (Horch et al. 2002). We compared conspicuousness between the two models for all our measurements 
of crab body colour reflectances and habitat background radiances. Conspicuousness was evaluated as colour of body areas that produced the greatest difference in spectral contrast $\left(\Delta S_{\text {avian }}\right.$ or $\left.\Delta S_{\text {crab }}\right)$ or brightness contrast ( $\Delta B_{\text {avian }}$ or $\Delta B_{\text {crab }}$ ) for within-body comparisons (comparing different coloured areas on the crab) and against background comparisons (body colour viewed against background).

\section{Avian Vision Model}

The avian vision model was used to describe colour and brightness discriminations where vision is limited by photoreceptor noise. The model begins with photoreceptor photon capture (cone quantum catch), $Q_{c}$, which represents a certain level of excitation for cone class, $c$,
Colour differences between crab body parts, or between crab versus background, were evaluated as the differences in adjusted receptor signals, $\Delta f_{\mathrm{c}}$, and multiplied by the noise in each receptor channel. For example, $\Delta f_{\mathrm{c}}=\ln \left(q_{\mathrm{L}}\right.$ (manus $\left.)\right)-\ln \left(q_{\mathrm{L}}\right.$ (mouthpart $\left.)\right)$ for within-body contrasts or $\Delta f_{\mathrm{c}}=\ln \left(q_{\mathrm{L}}\right.$ (manus $\left.)\right)-\ln \left(\mathrm{q}_{\mathrm{L}}(\right.$ mudball $\left.)\right)$ for background contrast. Noise in each receptor channel, $\omega_{c}$, is assumed to be independent of quantal fluctuations and was set by the relative number of receptor types within a European starling receptive field $\left(\omega_{\mathrm{U}}=1.0 ; \omega_{\mathrm{S}}=\right.$ $0.857 ; \omega_{\mathrm{M}}=0.520 ; \omega_{\mathrm{L}}=0.515$; where $\mathrm{U}=$ ultraviolet sensitive; $\mathrm{S}=$ shortwave sensitive, $\mathrm{M}=$ midwave sensitivity, $\mathrm{L}=$ longwave sensitivity and cone proportions; J. Partridge, personal communication).

The spectral distance in colour space, $\Delta S$, our metric for colour contrast by an avian viewer, is defined as in Vorobyev et al. (1998):

$$
(\Delta S)^{2}=\frac{\left(\omega_{\mathrm{U}} \omega_{\mathrm{S}}\right)^{2}\left(\Delta f_{\mathrm{L}}-\Delta f_{\mathrm{M}}\right)^{2}+\left(\omega_{\mathrm{U}} \omega_{\mathrm{M}}\right)^{2}\left(\Delta f_{\mathrm{L}}-\Delta f_{\mathrm{S}}\right)^{2}+\left(\omega_{\mathrm{U}} \omega_{\mathrm{L}}\right)^{2}\left(\Delta f_{\mathrm{M}}-\Delta f_{\mathrm{S}}\right)^{2}+\left(\omega_{\mathrm{S}} \omega_{\mathrm{M}}\right)^{2}\left(\Delta f_{\mathrm{L}}-\Delta f_{\mathrm{U}}\right)^{2}+\left(\omega_{\mathrm{S}} \omega_{\mathrm{L}}\right)^{2}\left(\Delta f_{\mathrm{M}}-\Delta f_{\mathrm{U}}\right)^{2}+\left(\omega_{\mathrm{M}} \omega_{\mathrm{L}}\right)^{2}\left(\Delta f_{\mathrm{S}}-\Delta f_{\mathrm{U}}\right)^{2}}{\left(\left(\omega_{\mathrm{U}} \omega_{\mathrm{S}} \omega_{\mathrm{M}}\right)^{2}+\left(\omega_{\mathrm{U}} \omega_{\mathrm{S}} \omega_{\mathrm{L}}\right)^{2}+\left(\omega_{\mathrm{U}} \omega_{\mathrm{M}} \omega_{\mathrm{L}}\right)^{2}+\left(\omega_{\mathrm{S}} \omega_{\mathrm{M}} \omega_{\mathrm{L}}\right)^{2}\right)}
$$

while viewing target, $t$, stimuli under specific irradiance measurements:

$$
Q_{c}=\sum_{\lambda=300}^{700} I_{i}(\lambda) R_{t}(\lambda) A_{c}(\lambda)
$$

Cone quantum catch of target radiances, $Q_{c}$, is evaluated as the summed product of illuminating irradiance $I_{i}(\lambda)$, target reflectance (crab colour pattern) $R_{t}(\lambda)$, and the absorptance spectrum (including ocular or screening pigments where appropriate) $A_{c}(\lambda)$, for a given photoreceptor cone class $c$. The effective spectral sensitivities for each cone class after correcting for coloured oil droplet absorptance was based on the European starling, Sturnus vulgaris, visual measurements (Hart et al. 1998; J. Partridge, personal communication), including ultraviolet sensitive $\lambda_{\max }=371 \mathrm{~nm}$, shortwave sensitive $\lambda_{\max }=453 \mathrm{~nm}$, midwave sensitive $\lambda_{\max }=543 \mathrm{~nm}$, and longwave sensitive $\lambda_{\max }=605 \mathrm{~nm}$ cones using a rhodopsin (vitamin $\mathrm{A}_{1}$ based) template (Govardovskii et al. 2000). These photon capture responses are then adjusted for the adapting background light through a process known as the von Kries transformation, such that $q_{c}=k_{c} Q_{c}$ and

$$
k_{c}=1 / \sum_{\lambda=300}^{700} I_{b}(\lambda) A_{c}(\lambda)
$$

where $I_{b}(\lambda)$ is the sky irradiance of the adapting visual background.

The next stage in this visual model assumes that photoreceptor response follows the Weber-Fechner laws (Osorio et al. 1997; Vorobyev et al. 1998; Chiao et al. 2000), where the signal of each cone channel is proportional to the natural logarithm of the background adjusted quantum catch:

$$
f_{c}=\ln \left(q_{c}\right)
$$

Brightness contrast, or the achromatic processing channel, of the avian visual system is considered to be a function of double cones, usually spectrally identical long wavelength sensitive (LWS) cone photoreceptors (Siddiqi et al. 2004) or a combination of LWS and middle wavelength sensitive (MWS) cone inputs (Théry et al. 2005). Brightness contrast estimates for the potential bird predators in this system were evaluated in a similar fashion as spectral contrast, but evaluated in terms of the LWS cone only:

$$
\left(\Delta B_{\text {avian }}\right)^{2}=\left(\Delta f_{\mathrm{L}}\right)^{2} /\left(\omega_{\mathrm{L}}\right)^{2}
$$

\section{Crab Vision Model}

Microspectrophotometric (MSP) sampling of visual and screening pigment of $U$. tangeri suggests that it has only a single visual pigment with screening pigment combination across all ommatidia in its main rhabdoms (Jordão et al. 2007). The single-receptor class has a visual pigment absorbing maximally at $530 \mathrm{~nm}$, and with the screening pigment has an effective spectral sensitivity peak at $593 \mathrm{~nm}$ (Jordão et al. 2007). We used a normalized absorptance spectrum of this rhodopsin-based $\left(\mathrm{A}_{1}\right)$ visual pigment with an optical density of 0.006 and pathlength of $250 \mu \mathrm{m}$ along with the 0.1 optical density screening pigment to estimate the spectral sensitivity curve for $U$. tangeri. We computed cone quantum catch and background adaptation using the estimated $U$. tangeri effective photoreceptor absorptance spectrum (Jordão et al. 2007) and equations (1)-(3) from above to estimate crab brightness contrast in a similar fashion as that of avian brightness contrast:

$$
\left(\Delta B_{\text {crab }}\right)^{2}=\left(\Delta f_{\mathrm{L}}\right)^{2} /\left(\omega_{\mathrm{L}}\right)^{2}
$$

where $\omega_{\mathrm{L}}$ represented the estimated noise (Weber fraction) in the LWS visual pigment cells of $U$. tangeri. With no 
noise estimates known for crabs, we assigned $\omega_{\mathrm{L}}=0.12$ based on physiological recordings from honeybee, Apis mellifera, single LWS cells (Peitsch 1992; Hempel De Ibarra et al. 2000).

Another study using electroretinogram techniques has found evidence for two pigment types in another species of fiddler crab, U. thayeri. Horch et al. (2002) found evidence for a rhodopsin $\left(A_{1}\right)$ based visual pigment with peak sensitivity near $430 \mathrm{~nm}$ in $U$. thayeri. Furthermore, there is good behavioural evidence for colour vision in one fiddler species (Detto et al. 2006), suggesting that some fiddler crabs may use a dichromatic visual system to discriminate amongst individuals based on colour (see also Hyatt 1975). As a conservative, yet comprehensive, approach to modelling the crabs visual system, we estimated crab brightness contrast perception using the one LWS pigment type measured in $U$. tangeri with MSP (590 nm peak sensitivity), and estimated a possible opponency channel using the SWS pigment peak found in the $U$. thayeri study (430 $\mathrm{nm}$ peak sensitivity). We used Govardovskii et al. (2000) rhodopsin template to produce a spectral absorptance curve with a 430-nm peak assuming the same optical density and pathlength measured with MSP for LWS visual pigments in $U$. tangeri (O.D. $=0.006$; pathlength $=250 \mu \mathrm{m})$. For this hypothetical crab opponency channel, we assumed that discrimination processes were also limited by receptor noise (Vorobyev et al. 2001). Using the same Weber-Fechner responses from equation (3) above, these were then evaluated for dichromatic vision as follows (as in Vorobyev \& Osorio 1998; Chiao et al. 2000):

$$
\left(\Delta S_{\text {crab }}\right)^{2}=\left(\Delta f_{\mathrm{L}}-\Delta f_{\mathrm{S}}\right)^{2} /\left(\omega_{\mathrm{L}}+\omega_{\mathrm{S}}\right)^{2}
$$

\section{Contrast: Background and Within Body}

In this investigation, estimates of colour and brightness contrast ( $\Delta S$ and $\Delta B$, respectively) were used to estimate a viewer's ability to discriminate differences between a crab body part and a particular background (background contrast) or differences between two crab body parts (within-body contrast).

\section{RESULTS}

Male and female body coloration differed the most in claw spectral reflectances (Figs 1 and 2). Comparing male and female manus total reflectance intensity, $\log \left(\sum_{\lambda=300}^{700} R(\lambda)\right)$, indicated that male major claws significantly reflected more light per unit surface area than female claws (mean $\log \Sigma R(\lambda) \pm 1$ SE, male manus (exterior): $2.14 \pm 0.03$, female right claw: $1.68 \pm 0.06$, $t=6.25, P_{\text {two tail }}<0.001$; male manus: $2.18 \pm 0.02$, female left claw: $\left.1.77 \pm 0.07, t=5.32, P_{\text {two tail }}<0.001\right)$. However, the male minor claw was not significantly brighter than the female claws (male minor claw: $1.95 \pm 0.06$, female left claw: $1.77 \pm 0.07, t=1.88, P_{\text {two tail }}<0.068$ ). While three locations on each male's major claw were measured (exterior dactyl and pollex, exterior manus, and inner dactyl and pollex), all subsequent sexual dimorphic comparisons used the exterior manus of the male major claw, since this represented the most equivalent area to that measured on female claws. Similarly, all major male claw comparisons were made relative to the female left claw, as it represented the brighter of the two female claws.

Background radiance measurements were collected on three days (20, 22 and 24 July) in front of burrows with light and dark mudballs. Comparison of radiance intensity $\left(\sum_{\lambda=300}^{700} L(\lambda)\right)$ between sand and mudball radiance measurements showed no difference between sand and mudball intensities for burrows with 'light-coloured' mudballs (20 July at 1615 hours: 'light' burrows: $N=32$ paired radiance fluxes $(\Sigma L)$, paired $t$ test $=0.12, P=0.90$; 22 July at 1715 hours: 'light' burrows: $N=16$ paired radiances, paired $t$ test $=1.82, P=0.09 ; 24$ July at 1815 hours: $N=48$ paired radiances, paired $t$ test $=0.43, P=0.66$ ). Burrows with 'dark-coloured' mudballs were also generally the same intensity as the surrounding sand, however, with one location showing significantly darker mudballs than the surrounding sand ( 22 July at 1715 hours: 'dark' burrows: $N=31$ paired radiances, mean $\pm 1 \mathrm{SE}$ of 'mudball' $\Sigma L=25.91 \pm 2.29 u \mathrm{E} / \mathrm{m}^{2} / \mathrm{s} / \mathrm{sr}$ and 'sand' $\Sigma L=39.98 \pm$ $1.87 u \mathrm{E} / \mathrm{m}^{2} / \mathrm{s} / \mathrm{sr}$, paired $t$ test $\left.=5.46 ; P<0.0001\right)$. An example of mudballs being darker than the surrounding sand near the burrow is shown in Fig. 1d.

Given the spectral similarity between estimates of radiance (calculated as the product of mudball reflectance and habitat irradiance measurements) and field radiance measurements (Fig. 2c; correlation between measured and estimated radiances for light mudball, $r=0.997$, and dark mudball, $r=0.982$ ), we proceeded to use background reflectance measurements in our conspicuousness evaluations. For crab viewers, the relative conspicuousness of these different body parts depends on the background they are viewed against. The male dark mouthpart and exterior manus (Fig. 2) produced greater brightness contrast $\left(\Delta B_{\text {crab }}\right)$ than female equivalent parts across all backgrounds examined (Fig. $3 \mathrm{a}-\mathrm{c}$ ). In general, male body parts were more conspicuous than female equivalent body parts against dark backgrounds such as the dark mudball (Fig. 3a) and mudflat vegetation (Fig. 3c), compared to light backgrounds (Fig. 3b). In a hypothetical crab colour channel $\left(\Delta S_{\text {crab }}\right)$, only the male mouthparts were significantly more conspicuous than female mouthparts against all relevant backgrounds (Fig. 3d-f). Interestingly, the female claw showed hypothetically greater spectral contrast than the male manus against dark backgrounds (Fig. 3d, f). The relative pattern of conspicuousness between the sexes and against different backgrounds and viewers was equivalent whether using early (data not shown) or late (Fig. 3) afternoon irradiance measurements. Hence, for all subsequent conspicuousness assessments, we used only late afternoon irradiance measurements in conspicuous modelling.

Examining crab conspicuousness for a potential avian viewer, we found that the pattern of relative conspicuousness between sexes and body parts was very similar to that of a crab viewer (Fig. 4). Males were more conspicuous than females for most body parts and against all backgrounds in terms of brightness contrast (Fig. $4 \mathrm{a}-\mathrm{c}$ ). The 

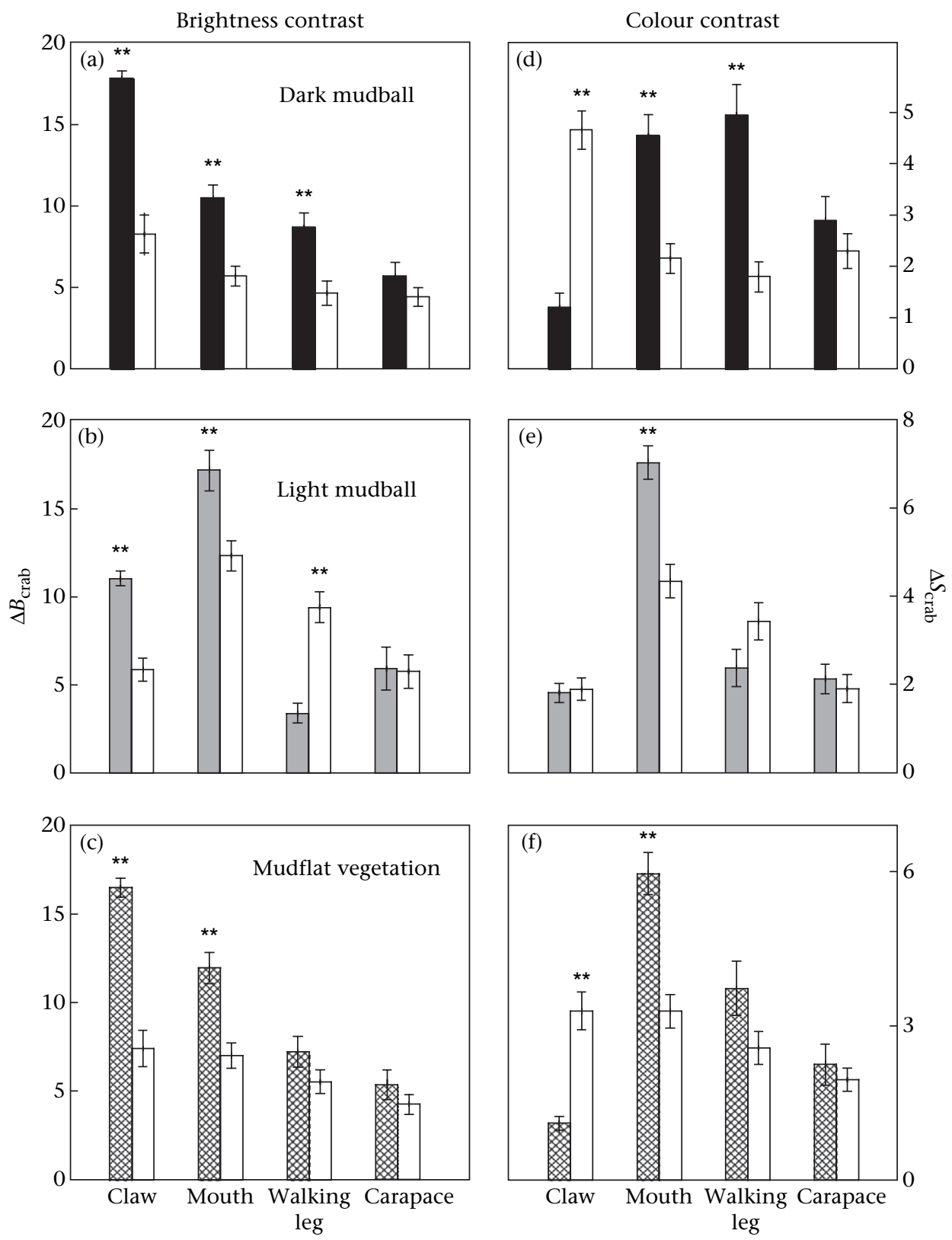

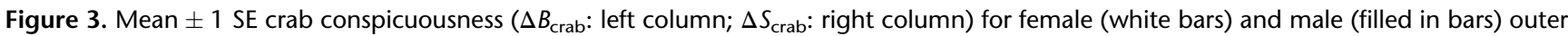
claws, mouth, ambulatory leg and carapace reflectance against different backgrounds. (a, d) Dark mudballs. (b, e) Light mudballs. (c, f) mudflat vegetation (Zostera marina). ${ }^{* *} P<0.01$ significant difference in contrast estimates $\left(\Delta B_{\text {crab }}\right.$ or $\Delta S_{\text {crab }}$ ) using a two-tailed $t$ test across all individuals $(N=20$ males and 20 females).

only body part that showed a consistent nonsexually dimorphic pattern of conspicuousness was the carapace (in both brightness and colour contrast channels). Similar to the crab modelling results, female crab claw parts were significantly more conspicuous in terms of spectral contrast than those of males against darker backgrounds (dark mudball, mudflat vegetation; Fig. 4d, f).

The male major claw has two relevant sides to it: the exterior and the interior. The exterior major claw (manus, dactyl and pollex) is viewed against various substratebound backgrounds; while the interior major claw is seen only when a signalling male opens up his major claw and waves it above his head. In these circumstances, the inner dactyl and pollex of the male claw (Fig. 1) are usually viewed against the background sky. A comparison of the three major claw areas (exterior dactyl and pollex, exterior manus, and inner dactyl and pollex) against all possible viewing backgrounds showed that the major claw reflectances differed in their conspicuousness levels in a relevant background-dependent fashion (Fig. 5). Each set of three claw areas showed significant differences in conspicuousness across 20 males $(F=)$ 10.05, $P<0.001$ and post hoc pairwise comparisons showed significant differences between exterior claw areas(manus and exterior dactyl and pollex) relative to interior claw area (inner dactyl and pollex). The most conspicuous background for all 

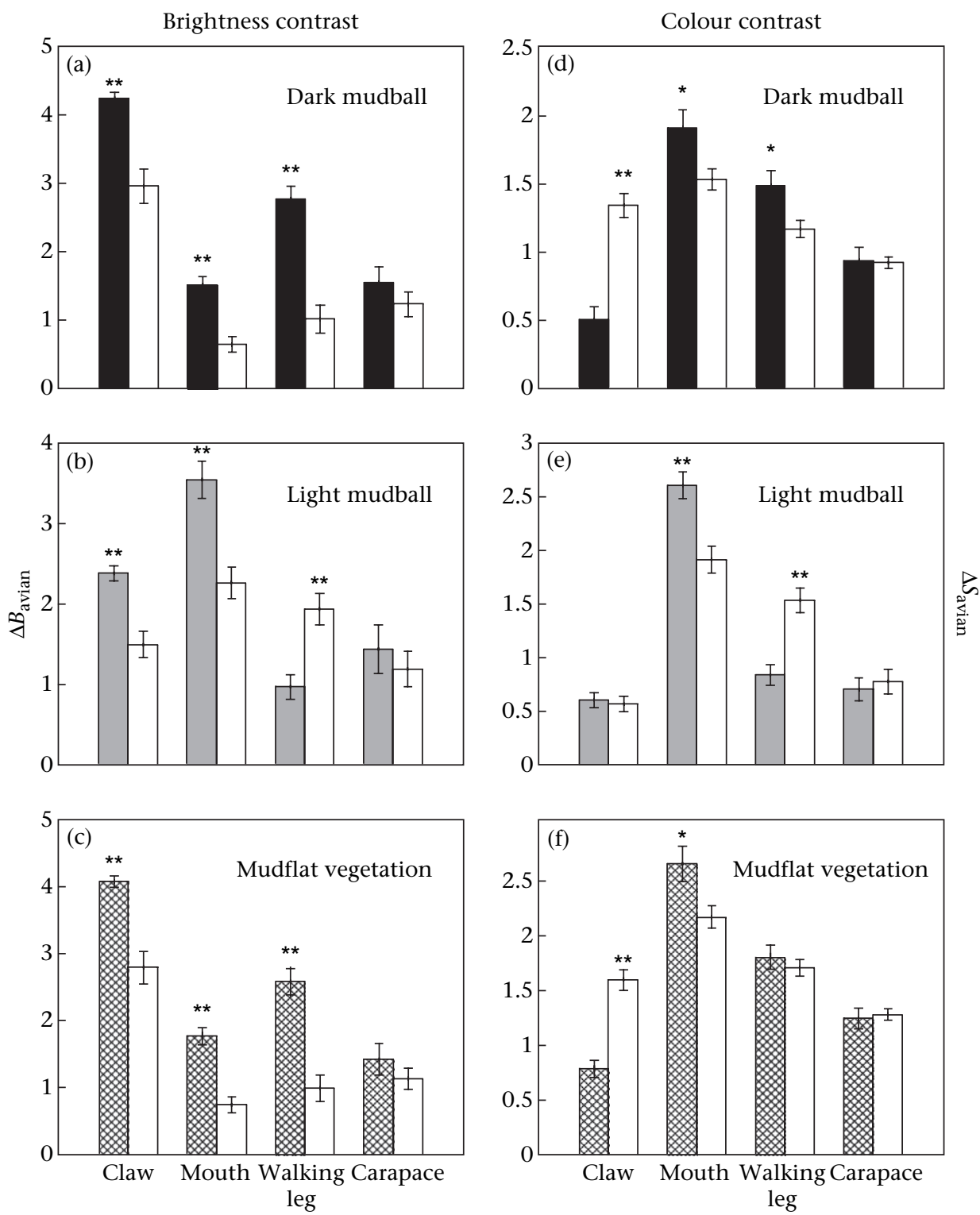

Figure 4. Mean $\pm 1 \mathrm{SE}$ conspicuousness of crab body parts for an avian viewer ( $\Delta B_{\text {avian: }}$ left column; $\Delta S_{\text {avian: }}$ right column) for female (white bars) and male (filled in bars) outer claws, mouth, walking leg and carapace reflectance against different backgrounds. (a, d) Dark mudballs. (b, e) Light mudballs. (c, f) mudflat vegetation (Zostera marina). ${ }^{*} P<0.01$ and ${ }^{*} P<0.05$ in contrast estimates $\left(\Delta B_{\text {avian }}\right.$ or $\left.\Delta S_{\text {avian }}\right)$ using a twotailed paired $t$ test across all individuals $(N=20$ males and 20 females).

claw areas was the dark mudball, although the relative conspicuousness across claw parts differed by background. In the brightness channel, $\Delta B_{\text {crab }}$, both of the exterior male claw reflectance measurements (M: manus; E: exterior dactyl and pollex) were significantly more conspicuous than the inner dactyl and pollex (I) regions against all substrate-bound backgrounds (dark and light mudballs, mudflat vegetation). The inner dactyl and pollex produced significantly greater conspicuousness in the brightness $\left(\Delta B_{\text {crab }}\right)$ channel against the sky, and in the (hypothetical) colour $\left(\Delta S_{\text {crab }}\right)$ channel against all backgrounds except the light mudballs (Fig. 5).

The relative conspicuousness of different body parts depended not only on the background, but the viewer as well (Tables 1 and 2). In general, the claws of both males and females were most conspicuous relative to other body parts when viewed against dark backgrounds (dark mudballs and mudflat vegetation; Figs 3 and 4). However, when viewed against light sand, the most conspicuous body parts for both males and females were the dark mouthparts. A similar pattern of relative ranking occured when examined from an avian predator's perspective (Table 2, Fig. 4). The dorsal carapace was predominantly the least conspicuous body part to both crab (Fig. 3) and avian (Fig. 4) viewers across most backgrounds and in both the brightness and spectral channels.

The two body parts that were most conspicuous in the different environments (claws and mouthparts) created the greatest within-body contrast estimates (spectral or brightness contrast of two reflectances independent of 

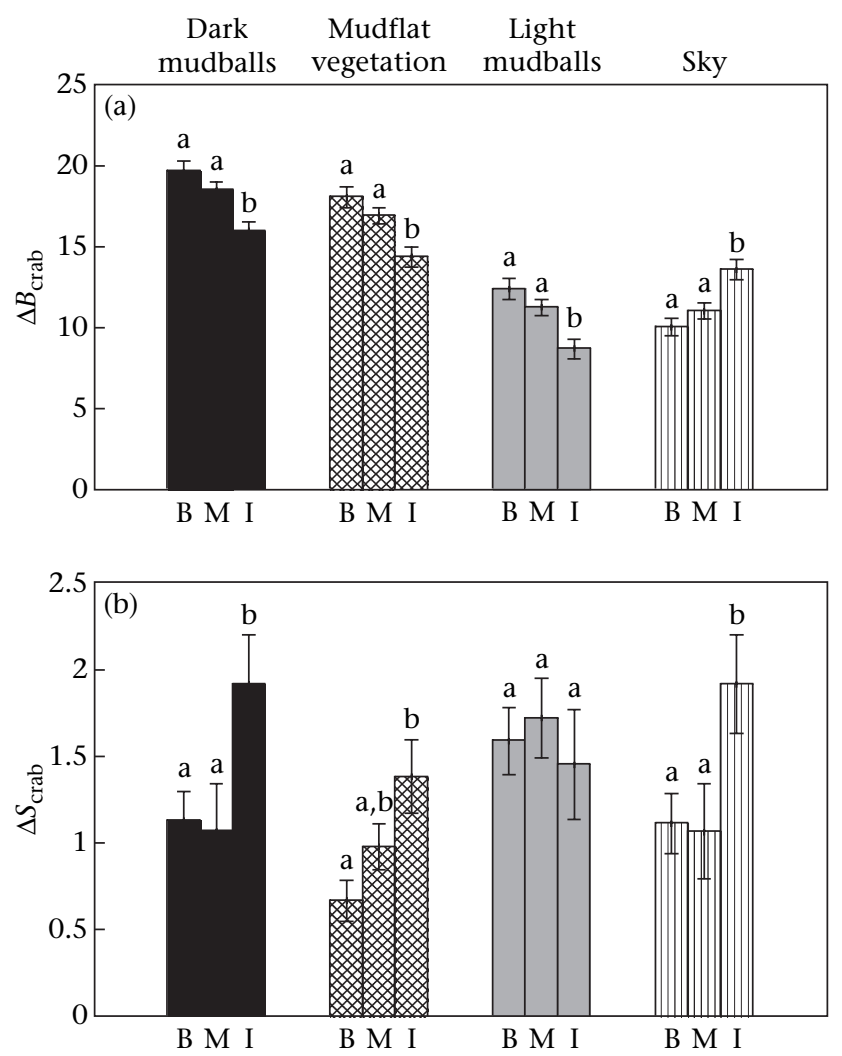

Figure 5. Male claw contrast comparisons. Exterior (manus (M); dactyl and pollex (B)), and interior (inner dactyl and pollex (I)) regions from Fig. 1a were compared for conspicuousness against different viewing backgrounds by a potential conspecific. (a) Brightness contrast $\left(\Delta B_{\text {crab }}\right)$ and (b) spectral contrast $\left(\Delta S_{\text {crab }}\right)$ of claw parts by background. Different letters indicate significant different pairwise comparisons at the $P<0.05$ level.

background; Fig. 6). Claw and mouthparts produced higher within-body contrast estimates than claw and blue dots (a male-specific character). When estimating within-body contrast for equivalent body parts, males again showed significantly greater conspicuousness than females (Fig. 6). In terms of brightness contrast, the claw (manus and exterior dactyl and pollex) resting across the mouth region (see Fig. 1) produced the greatest degree of within-body contrast of all possible body part comparisons (Fig. 6a, c). Meanwhile for a hypothetical colour contrast channel, the mouth and leg produced the greatest within-body contrast (Fig. 6b, d).

\section{DISCUSSION}

\section{Sexually Dimorphic Coloration}

Uca tangeri has sexually dimorphic coloration that is most pronounced in the claw (Figs 1-3). This sexual dimorphism is found in other mudflat dwelling crabs that use claws for social signalling, such as Heloecius cordiformis (Detto et al. 2004). Our findings suggest that sexually dichromatic coloration (Figs 1 and 2 ) leads to sexually dimorphic conspicuousness (Figs 3, 4 and 6): males are
Table 1. Rank order of body part conspicuousness

\begin{tabular}{|c|c|c|c|c|c|c|c|}
\hline \multicolumn{2}{|l|}{ Background } & \multicolumn{2}{|c|}{$\mathrm{DMB}$} & \multicolumn{2}{|c|}{ VEG } & \multicolumn{2}{|c|}{ LMB } \\
\hline Male (M) & Female $(F)$ & M & $\mathrm{F}$ & $M$ & $\mathrm{~F}$ & M & $\mathrm{F}$ \\
\hline Major claw (manus) & Left claw & 1 & 1 & 1 & 1 & 2 & 3 \\
\hline Minor claw & Right claw & 2 & 2 & 2 & 2 & 3 & 4 \\
\hline \multicolumn{2}{|l|}{ Mouthpart } & 3 & 3 & 3 & 3 & 1 & 1 \\
\hline \multicolumn{2}{|c|}{ Dorsal carapace } & 5 & 5 & 5 & 5 & 4 & 5 \\
\hline \multicolumn{2}{|c|}{ Ambulatory leg } & 4 & 4 & 4 & 4 & 5 & 2 \\
\hline
\end{tabular}

All claw measurements are from the exterior claw (major claw area; see Fig. 1). Conspicuousness (1: most conspicuous to 5: least conspicuous) from conspecifics' point of view $\left(\Delta B_{\text {crab }}\right)$ against different backgrounds: dark mudballs (DMB), mudflat vegetation (VEG), and light mudballs (LMB).

generally more conspicuous than females and body parts involved in signalling are more conspicuous than nonsignalling parts. Male claws and mouthparts are significantly more conspicuous than those of females against all substrate-bound backgrounds (light and dark substrate, mudflat vegetation) in the brightness contrast channel. Meanwhile, body parts that are more likely to be viewed by overhead predators (dorsal carapace) show no sexual dimorphism and are generally the least conspicuous body parts (Figs 3 and 4, Tables 1 and 2).

What is particularly interesting is that the body part that is most conspicuous to an avian predator against the light-coloured backgrounds (dark mouthparts against sand) is less likely to be visible to a bird viewing the crab from above. While avian predators flying above have access to view the relatively cryptic carapace (e.g. Land 1999), only standing (grazing) predators are likely to have a view of the highly conspicuous mouth parts, yet not for long, as crabs respond evasively to grazing predators by running to their burrow when predators (e.g. terns) are 5-10 $\mathrm{m}$ away (Hemmi 2005).

It should be noted that our reflectance measurements did not take into account any possible change in reflectance due to stress or handling. Reflectance measurements on other fiddler crab species with more brilliant and diverse coloration (Uca vomeris) have shown that some carapace coloration (white and blue) becomes duller

Table 2. Rank order of body part conspicuousness

\begin{tabular}{|c|c|c|c|c|c|c|c|}
\hline \multicolumn{2}{|l|}{ Background } & \multicolumn{2}{|c|}{ DMB } & \multicolumn{2}{|c|}{ VEG } & \multicolumn{2}{|c|}{ LMB } \\
\hline Male (M) & Female $(F)$ & M & $\mathrm{F}$ & M & $\mathrm{F}$ & M & $\mathrm{F}$ \\
\hline Major claw (manus) & Left claw & 1 & 1 & 1 & 1 & 2 & 3 \\
\hline Minor claw & Right claw & 2 & 2 & 2 & 2 & 3 & 4 \\
\hline \multicolumn{2}{|c|}{ Mouthpart } & 5 & 5 & 4 & 5 & 1 & 1 \\
\hline \multicolumn{2}{|c|}{ Dorsal carapace } & 4 & 3 & 5 & 3 & 4 & 5 \\
\hline \multicolumn{2}{|c|}{ Ambulatory leg } & 3 & 4 & 3 & 4 & 5 & 2 \\
\hline
\end{tabular}

Conspicuousness (1: most conspicuous to 5 : least conspicuous) from potential avian predator's point of view $\left(\Delta B_{\text {avian }}\right)$ against different backgrounds: dark mudballs (DMB), mudflat vegetation (VEG), and light mudballs (LMB). 

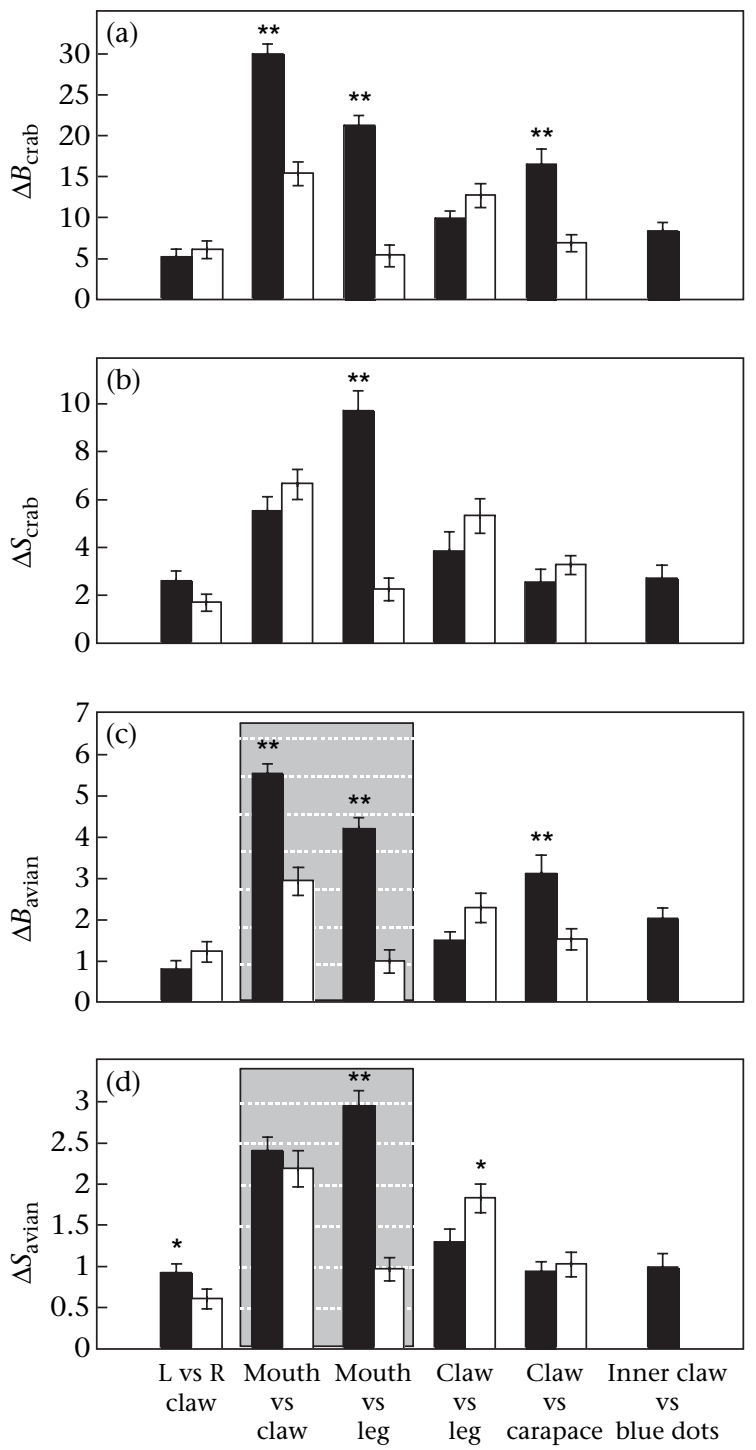

Figure 6. Mean \pm 1 SE within-body contrast (WBC) estimates for males (black) and female (white) for different viewers. WBC measurements are for 20 female and 19 male $U$. tangeri. ${ }^{* *} P<0.01$ and ${ }^{*} P<0.05$ using a two-tailed $t$ test. WBC estimates were made on equivalent body parts. The shaded contrast estimates highlight body parts that are less visible to avian predators flying above.

as a result of handling stress, while claw coloration appears to be more stable with no change in reflectance properties with handling time (Zeil \& Hofmann 2001; Hemmi et al. 2006). Unlike $U$. vomeris (Hemmi et al. 2006), U. tangeri showed no visible change to the human eye in coloration as a result of handling. This may be due to the differences in the type of carapace coloration: $U$. vomeris has brilliantly blue, white and dark coloration, whereas $U$. tangeri has a more uniform dark coloration on its carapace (Fig. 1). While the claw coloration is expected to be stable (Hemmi et al. 2001), the finding that fiddler crabs respond to stress by dulling their white coloration suggests that our contrast estimates for the bright white claw areas are likely to be underestimates of the potential contrast viewed in the wild.

\section{Different Displaying Backgrounds}

Differences in conspicuousness between the sexes and between body parts show some dependence on visual background. Males were significantly more conspicuous than females across the range of ecologically relevant backgrounds (substrate and mudflat vegetation; Figs 3 and 4), particularly in the brightness contrast channel. The few exceptions to this came when examining contrast in a hypothetical crab colour channel, where female claws showed greater contrast $\left(\Delta S_{\text {crab }}\right)$ against dark backgrounds. Against dark backgrounds, such as the dark mudballs and salt marsh vegetation, the male claw showed the greatest brightness contrast of all body parts to both conspecifics and potential avian predators (Figs 3 and 4, Tables 1 and 2). Against lighter backgrounds such as sand (light mudballs), however, the claw was less conspicuous than the mouthpart, suggesting that mouthparts may play a larger role in signalling behaviour than currently thought.

The difference in conspicuousness of the male major claw relative to background (twice as conspicuous against the darker substrates than the light substrate, Fig. 3) suggests that males could potentially enhance their conspicuousness by selectively choosing burrow backgrounds. At the moment, there is no information on whether males show any selectivity in background materials, or whether their access to all substrate types is equally available. For instance, in environments with little anoxic mud (the likely source for the dark mudballs), do males select burrow sites next to dark vegetation (as shown in Fig. 1a)? Some studies have observed that larger males usually burrow higher in the mudflat zones next to vegetation (Klaassen \& Ens 1993). Whether males are showing selectivity for visual background or organic content of the substrate requires further manipulation. Males in other species that achieve mating success by attracting females to specific locations, such as forest-lekking birds in the Neotropics, select specific display sites in the forest that maximize their conspicuousness (Endler \& Théry 1996).

Fine differences between inner and outer male claw coloration highlight the importance of background context when examining conspicuousness. Figure 5 shows that inner and outer dactyl and pollex reflectances significantly differed in brightness conspicuousness $\left(\Delta B_{\text {crab }}\right)$ depending on visual background. Exterior dactyl and pollex reflectances showed greater conspicuousness against all substrate-bound backgrounds (dark and light mudballs, and mudflat vegetation). However, the inner dactyl and pollex were more conspicuous than the outer dactyl and pollex against the most common signalling background, the sky (Fig. 5a, b). A hypothetical colour discrimination channel $\left(\Delta S_{\text {crab }}\right)$ did not show this consistent difference in conspicuousness with changes in substrate versus sky backgrounds (Fig. 5b). The bias for brightness contrast of specific claw parts against the most relevant visual background makes sense if the waving claw attempts to get the attention of females from a distance. Visual research has indicated that long-range vision, in both birds and invertebrates, is likely to be dominated by brightness or achromatic cues (Osorio et al. 1999; Spaethe et al. 2001; Théry et al. 2005). 


\section{Within-body Contrast}

We found significant sexual dimorphism for withinbody contrast estimates (Fig. 6), supporting our prediction for great conspicuousness for sex recognition features (claw resting against mouth). The male mouth-claw, mouth-leg and claw-carapace contrasts showed much greater values than the equivalent comparison in females. A similar pattern of sexually dimorphic within-body contrasts was also found when examining conspicuousness from the

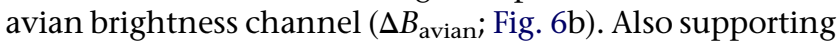
this prediction were specific comparisons that produced the greatest within-body contrast for the avian visual system, mouth versus claw and mouth versus leg, which are mainly visible to crab conspecifics and potentially less visible to potential predators flying from above (Fig. 6c, d).

\section{Avian versus Crab Viewers}

The same body parts that were most and least conspicuous in each habitat for crab viewers had the same relative positions for avian viewers (Figs 3 and 4, Tables 1 and 2). Our prediction that carapace and legs should be the most cryptic, given that they are likely to be the first body parts seen by flying avian predators, was generally supported. Carapace and walking legs were the least conspicuous of all body parts against the light sand (Fig. 4, Table 2), and carapace was the least conspicuous body part in the brightness channel against dark backgrounds (Fig. 4, Table 2). Cryptic carapace coloration appears to be driven by predation pressure in other fiddler crab species. In Australia, recent work (Hemmi et al. 2006) on a brightly coloured fiddler crab with diverse carapace coloration (U. vomeris) showed that carapace coloration varies with predation threat. In populations with high avian population densities, coloration is muted and dull, whereas in areas with fewer birds, the coloration is bright blue and white, suggestive of a communication role. Uca tangeri meanwhile, showed no conspicuous coloration on its carapace or legs, but rather biased its conspicuous body parts to regions that were more frontal and directed towards females (mouth and claw).

While avian predation in this specific population of fiddler crab has not been quantified, there are reports of female-biased differential predation in several species of fiddler crabs. If females do experience differential predation, then we would expect females to be less conspicuous than males to a possible predator and that is what we found. In our characterization of conspicuousness, males were more conspicuous than females to avian predators (Figs 4 and 6) with only a few exceptions. Female fiddler crab claws were nearly as inconspicuous as carapaces against the sand, a light-coloured background (Fig. 4b). Male claws were more conspicuous against the carapace than female claws (Fig. 6c) in the brightness, and putatively distance-viewing, channel (Théry et al. 2005). Hence, male signalling (claw-waving) and signal properties (claw reflectance) appear to place this sex at greater risk of visual predation than the other sex.

Within-body contrast measures were much higher for body regions that are likely to be more visible to conspecifics and less visible to an overhead avian predator (e.g. mouth to claw and mouth to leg contrasts; Fig. 6). The difference in claw and mouthpart conspicuousness relative to carapace conspicuousness (Figs 3, 4 and 6, Tables 1 and 2) suggests that male $U$. tangeri maximize conspicuousness of display elements that are more visible to conspecifics than to avian predator flying above. Here, we suggest that male $U$. tangeri are maximizing conspicuousness in one viewing angle (towards conspecifics) while minimizing conspicuousness from a potential predator's viewing angle (flying overhead). Such directional-bias in conspicuousness has been shown in other species, such as the Eclectus parrots (Heinsohn et al. 2005), that solve the balance between conspecific and predator detection by maximizing conspicuousness along specific viewing angles.

\section{Modifying Background to Increase Conspicuousness?}

Male $U$. tangeri, like many of its trans-Atlantic relatives, build sand structures (Christy et al. 2002, 2003a; Christy \& Backwell 2006). In U. tangeri, both males and females build balls of sand or mud, and differences in mudballing behaviour between the sexes of European fiddler crabs have been examined previously (Oliveira et al. 1998). Female mudballing behaviour appears to be a by-product of burrow digging, whereas male mudballing behaviour appears to have an important feature in signalling, potentially to both females and competitive males. Females are more likely to visit males with mudballs, and male-male interactions appear to be mediated by mudball number as well (Oliveira et al. 1998).

Given the social function of mudballing behaviour, we predicted that mudballs should increase a male's conspicuousness relative to other backgrounds (mudflat vegetation). Our predictions were partially supported. Overall, the most conspicuous background for a male's claw was the dark mudball, with both dark mudballs and mudflat vegetation providing higher brightness contrast conspicuous estimates, $\Delta B_{\text {crab }}$, for the major claw (Fig. 3a, c), than light mudballs (Fig. 3b). A hypothetical colour contrast

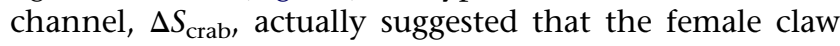
is more conspicuous than that of the male against natural and some mudball backgrounds (Fig. 3d, f). And conspicuousness against light backgrounds (light mudballs) shifts from the major claw as the most conspicuous body part to the mouth (Fig. 3b, e). While we are making the assumption that one function of mudballs might be to increase the conspicuousness of the male, it is also possible that they are independent of male signalling behaviour and act only as landmarks. A future behavioural experiment that compares female visits to males with high contrast mudballs versus lower contrast mudballs will help determine the role that mudballs serve in signalling display.

\section{Conclusions}

Our predictions about the visual ecology of fiddler crab were largely met by our results. Evolution has clearly favoured a body coloration that enhances intraspecific 
communication, especially in body parts that are particularly relevant for signalling behaviour, such as the males' major claw. A particular interesting example of this is how the outer and inner surfaces of the major claw are most conspicuous against the backgrounds that they are usually viewed against by conspecifics. Crypsis has also been fairly well preserved in body parts (carapace) that are first viewed by potential avian predators. Signalling parts (major claw) were the most conspicuous body parts, and the conspicuousness of such body parts was enhanced when viewed against particular crab-made backgrounds (e.g. dark mudballs).

\section{Acknowledgments}

We are indebted to Julian Partridge for providing the starling spectral sensitivity absorptance spectra, and to John Endler and John Melack for the use of spectrometry equipment. J.M.J. was funded by a Ph.D. fellowship from Fundação para a Ciência e Tecnologia (PRAXIS XXI/BD/ 19835/99). R.F.O. was supported by a plurianual program fund from Fundação para a Ciência e Tecnologia (RI \& D unit 331/94). M.E.C. was supported by a National Science Foundation pre-doctoral fellowship. We also thank the Ria Formosa Natural Park, Portugal for permission to work in their protected area and for logistic support.

\section{References}

Backwell, P. R. Y., Jennions, M. D., Christy, J. H. \& Schober, U. M. 1995. Pillar building in the fiddler crab Uca beebei: evidence for a condition-dependent ornament. Behavioral Ecology and Sociobiology, 36, 85-192.

Bildstein, K. L., McDowell, S. G. \& Brisbin, I. L. 1989. Consequences of sexual dimorphism in sand fiddler crabs, Uca pugilator: differential vulnerability to avian predation. Animal Behaviour, 37, 133-139.

Chiao, C.-C., Vorobyev, M., Cronin, T. W. \& Osorio, D. 2000. Spectral tuning of dichromats to natural scenes. Vision Research, 40, 3257-3271.

Christy, J. H. 1983. Female choice in the resource-defense mating system of the sand fiddler crab, Uca pugilator. Behavioral Ecology and Sociobiology, 12, 169-180.

Christy, J. H. 1988. Pillar function in the fiddler crab Uca beebei (II): competitive courtship signalling. Ethology, 78, 113-128.

Christy, J. H. 1995. Mimicry, mate choice, and the sensory trap hypothesis. American Naturalist, 146, 171-181.

Christy, J. H. \& Backwell, P. R. Y. 2006. No preference for exaggerated courtship signals in a sensory trap. Animal Behaviour, 71, 1239-1246.

Christy, J. H., Backwell, P. R. Y., Goshima, S. \& Kreuter, T. 2002. Sexual selection for structure building by courting male fiddler crabs: an experimental study of behavioural mechanisms. Behavioral Ecology, 13, 366-374.

Christy, J. H., Backwell, P. R. Y. \& Schober, U. M. 2003a. Intraspecific attractiveness of structures built by courting male fiddler crabs: experimental evidence of a sensory trap. Behavioral Ecology and Sociobiology, 53, 84-91.

Christy, J. H., Baum, J. K. \& Backwell, P. R. Y. 2003b. Attractiveness of sand hoods built by courting male fiddler crabs, Uca musica: test of a sensory trap hypothesis. Animal Behaviour, 66, 69-94.

Crane, J. 1975. Fiddler Crabs of the World. (Ocypodidae, Genus Uca). Princeton, New Jersey: Princeton University Press.
Cummings, M. E. 2004. Modelling divergence in luminance and chromatic detection performance across measured divergence in surfperch (Embiotocidae) habitats. Vision Research, 44, 1127-1145.

Cummings, M. E. \& Partridge, J. C. 2001. Visual pigments and optical habitats of surfperch (Embiotocidae) in the California kelp forest. Journal of Comparative Physiology A, 187, 875-889.

Darst, C. R., Cummings, M. E. \& Cannatella, D. C. 2006. A mechanism for diversity in warning signals: conspicuousness versus toxicity in poison frogs. Proceedings of the National Academy of Sciences, U.S.A., 103, 5852-5857.

Detto, T., Zeil, J., Magrath, R. D. \& Hunt, S. 2004. Sex, size and colour in a semi-terrestrial crab, Heloecius cordiformis $(\mathrm{H}$. Milne Edwards, 1837). Journal of Experimental Marine Biology and Ecology, 302, 1-15.

Detto, T., Backwell, P. R. Y., Hemmi, J. M. \& Zeil, J. 2006. Visually mediated species and neighbour recognition in fiddler crabs (Uca mjoebergi and Uca capricornis). Proceedings of the Royal Society of London, Series B, 273, 1661-1666.

Endler, J. A. 1987. Predation, light intensity and courtship behaviour in Poecilia reticulata (Pisces: Poeciliidae). Animal Behaviour, 35, 1376-1385.

Endler, J. A. \& Théry, M. 1996. Interacting effects of lek placement, display behaviour, ambient light, and color patterns in three neotropical forest-dwelling birds. American Naturalist, 148, 421-452.

Ens, B. J., Klaassen, M. \& Zwarts, L. 1993. Flocking and feeding in the fiddler crab (Uca tangeri): prey availability as risk-taking behaviour. Netherlands Journal of Sea Research, 31, 477-494.

Faria, M. M. 1995. Aspecto do Comportamento das Bocas-de-Cavalete Uca tangeri EIDOUX (Ocypodidae, Brachyura) no Parque Natural da Ria. Estudos Técnicos, No. 1. Olhão: Parque Natural da Ria Formosa.

Govardovskii, V. I., Fyhrquist, N., Reuter, T., Kuzmin, D. G. \& Donner, K. 2000. In search of the visual pigment. Visual Neuroscience, 17, 509-528.

von Hagen, H.-O. 1962. Freilandstudien zur sexual- und Fortpflanzungsbiologie von Uca tangeri in Andalusien. Zeitschrift für Morphologie und Ökologie der Tiere, 51, 611-725.

Hart, N. S., Partridge, J. C. \& Cuthill, I. C. 1998. Visual pigments, oil droplets and cone photoreceptor distribution in the European starling (Sturnus vulgaris). Journal of Experimental Biology, 201, 1433-1446.

Heinsohn, R., Legge, S. \& Endler, J. A. 2005. Extreme reversed sexual dichromatism in a bird without sex role reversal. Science, 309, 617-619.

Hemmi, J. M. 2005. Predator avoidance in fiddler crabs: 1. Escape decisions in relation to the risk of predation. Animal Behaviour, 69, 603-614.

Hemmi, J. M. \& Zeil, J. 2003a. Burrow surveillance in fiddler crabs. II sensory cues. Journal of Experimental Biology, 206, 3951-3961.

Hemmi, J. M. \& Zeil, J. 2003b. Robust judgement of inter-object distance by an arthropod. Nature, 421, 160-163.

Hemmi, J. M., Marshall, J., Pix, W., Vorobyev, M. \& Zeil, J. 2006. The variable colours of the fiddler crab Uca vomeris and their relation to background and predation. Journal of Experimental Biology, 209, 4140-4153.

Hempel De lbarra, N., Vorobyev, M., Brandt, R. \& Guirfa, M. 2000. Detection of bright and dim colours by honeybees. Journal of Experimental Biology, 203, 3289-3298.

Horch, K., Salmon, M. \& Forward, R. 2002. Evidence for a two pigment visual system in the fiddler crab, Uca thayeri. Journal of Comparative Physiology A, 188, 493-499.

Hyatt, G. W. 1975. Physiological and behavioural evidence for colour discrimination by fiddler crabs (Brachyura, Ocypodidae, genus Uca). In: Physiological Ecology of Estuarine Organisms (Ed. by F. J. Vernberg), pp. 333-365. Columbia: University of South Carolina Press. 
Jordão, J. M., Cronin, T. W. \& Oliveira, R. F. 2007. Spectral sensitivity of four species of fiddler crabs (Uca pugnax, Uca pugilator, Uca vomeris and Uca tangeri) measured by in situ microspectrophotometry. Journal of Experimental Biology, 210, 447-453.

Klaassen, M. \& Ens, B. J. 1993. Habitat selection and energetics of the fiddler crab (Uca tangeri). Netherlands Journal of Sea Research, 31, 495-502.

Koga, T., Backwell, P. R. Y., Christy, J. H., Murai, M. \& Kasuya, E. 2001. Male-biased predation of a fiddler crab. Animal Behaviour, 62, 201-207. doi:10.1006/anbe.2001.1740.

Land, M. F. 1999. The roles of head movements in the search and capture strategy of a tern (Aves, Laridae). Journal of Comparative Physiology A, 184, 265-272.

Land, M. F. \& Layne, J. 1995. The visual control of behaviour in fiddler crabs II. Tracking control systems in courtship and defence. Journal of Comparative Physiology A, 177, 81-90.

Latruffe, C., McGregor, P. K. \& Oliveira, R. F. 1999. Visual signalling and sexual selection in male fiddler crabs, Uca tangeri. Marine Ecology Progress Series, 189, 233-240.

Machado, J. L. G. H. C. 1996. Distribuição espacial e variação temporal dos comportamentos sociais em Uca tangeri. M.S. thesis, Mestrado em Etologia, ISPA, Lisboa.

Ödeen, A. \& Håstad, O. 2003. Complex distribution of avian colour vision systems revealed by sequencing the SWS1 opsin from total DNA. Molecular Biology and Evolution, 20, 855-861.

Oliveira, R. F. \& Custodio, M. R. 1998. Claw size, waving display and female choice in the European fiddler crab, Uca tangeri. Ethology Ecology and Evolution, 10, 241-251.

Oliveira, R. F., McGregor, P. K., Burford, F. L., Custódio, M. R. \& Latruffe, C. 1998. Functions of mudballing behaviour in the European fiddler crab Uca tangeri. Animal Behaviour, 55, 1299-1309.

Osorio, D., Miklosi, A. \& Gonda, Z. 1999. Visual ecology and perception of coloration patterns by domestic chicks. Evolutionary Ecology, 13, 673-689.

Peitsch, D. 1992. Contrast responses, signal to noise ratios and spectral sensitivities in photoreceptor cells of hymenopterans. Ph.D. thesis, Free University, Berlin.
Pope, D. 2000. Testing function of fiddler crab claw waving by manipulating social context. Behavioral Ecology and Sociobiology, 47, 432-437.

Pope, D. 2005. Waving in a crowd: fiddler crabs signal in networks. In: Animal Communication Networks (Ed. by P. McGregor), pp. 252-276. Cambridge: Cambridge University Press.

Ribeiro, P. D., Iribarne, O. O., Jaureguy, L., Navarro, D. \& Bogazzi, E. 2003. Variable sex-specific mortality due to shorebird predation on a fiddler crab. Canadian Journal of Zoology, 81, 1209-1221.

Siddiqi, A., Cronin, T., Loew, E. R., Vorobyev, M. \& Summers, K. 2004. Interspecific and intraspecific views of colour signals in the strawberry poison frog Dendrobates pumilio. Journal of Experimental Biology, 207, 2471-2485.

Spaethe, J., Tautz, J. \& Chittka, L. 2001. Visual constraints in foraging bumblebees: flower size and colour affect search time and flight behaviour. Proceedings of the National Academy of Sciences, U.S.A., 98, 3898-3903.

Théry, M., Debut, M., Gomez, D. \& Casas, J. 2005. Specific colour sensitivities of prey and predator explain camouflage in different visual systems. Behavioral Ecology, 16, 25-29.

Vorobyev, M. \& Osorio, D. 1998. Receptor noise as a determinant of colour thresholds. Proceedings of the Royal Society of London, Series $B, 265,351-358$.

Vorobyev, M., Osorio, D., Bennett, A. T. D., Marshall, N. J. \& Cuthill, I. C. 1998. Tetrachromacy, oil droplets and bird plumage colours. Journal of Comparative Physiology A, 183, 621-633.

Vorobyev, M., Brandt, R., Peitsch, D., Laughlin, S. B. \& Menzel, R. 2001. Colour thresholds and receptor noise: behaviour and physiology compared. Vision Research, 41, 639-653.

Wolf, P. L., Shanholtzer, S. F. \& Reimold, R. J. 1975. Population estimates for Uca pugnax (Smith, 1870) on the Duplin estuary marsh, Georgia, U.S.A. (Decapoda Brachyura, Ocypodidae). Crustaceana, 29, 79-91.

Zeil, J. \& Hemmi, J. M. 2006. The visual ecology of fiddler crabs. Journal of Comparative Physiology A, 192, 1-25.

Zeil, J. \& Hofmann, M. 2001. Signals from 'crabworld': cuticular reflections in a fiddler crab colony. Journal of Experimental Biology, 204, 2561-2569. 